\title{
A Systematic Review of Problem Based Learning in Education*
}

\author{
Mohamad Ikram Zakaria”, Siti Mistima Maat, Fariza Khalid \\ Faculty of Education, Universiti Kebangsaan Malaysia, Bangi Selangor, Malaysia \\ Email: "gbs_916@yahoo.com
}

How to cite this paper: Zakaria, M. I., Maat, S. M., \& Khalid, F. (2019). A Systematic Review of Problem Based Learning in Education. Creative Education, 10, 2671-2688. https://doi.org/10.4236/ce.2019.1012194

Received: October 16, 2019

Accepted: November 25, 2019

Published: November 28, 2019

Copyright (c) 2019 by author(s) and Scientific Research Publishing Inc. This work is licensed under the Creative Commons Attribution International License (CC BY 4.0).

http://creativecommons.org/licenses/by/4.0/ (c) (i) Open Access

\begin{abstract}
The implementation of problem-based learning method in education within various disciplines of knowledge cannot be denied. The method is able to improve the traditional learning paradigm accommodating to the 21st century learning. The main aim of this review is to investigate the findings of studies related to the disciplines involving Problem Based Learning and its effects on education. The study uses a systematic approach analysis and synthesizes 43 articles from the year 2015 until 2018 including peer review articles and full text articles from ERIC and Google Scholar. It shows that the quantitative approach is the most used research method in investigating the disciplines applying PBL and the effects of such method towards education. This review involves various levels of education that use PBL as a method of teaching and learning. Overall, the results of this study show that Mathematics education is the discipline that uses PBL the most in teaching and learning. By and large, 95\% of its users believe that PBL has positive impacts towards education and can be used as an alternative method at any level of education.
\end{abstract}

\section{Keywords}

Problem Based Learning (PBL), Systematic Approach, Disciplines, Effect, Education

\section{Introduction}

An effective teaching and learning process is able to create a fun learning environment in the classroom. Previous studies have shown that an effective teaching method is one of the factors that strongly influence the pupils' achievement in learning (Missildine, Fountain, Summers, \& Gosselin, 2013). In addition, the diversity of teaching methods and strategies can help pupils to undertake the ${ }^{*} \mathrm{PBL}$ is a learning method focusing on solving problem. 
process of problem solving, understanding theory, using knowledge and skills in solving problems (Schultz, Duffield, Rasmussen, \& Wageman, 2014). If the teachers are able to deliver the content effectively, then the quality of learning can be increased besides being able to encourage active participation among pupils. Pupils will be actively explored, instilling values, acquiring knowledge, skills and shaping themselves to be competent humans. Problem-based learning (PBL) is one of the methods that can be used to endorse active learning based on the social constructivism concept (Allen, Donham, \& Bernhardt, 2011). Various studies have been carried out to analyze the role of this method in improving the quality of learning involving skills to generate a variety of ideas in order to create practical and effective solutions (Chuan et al., 2011). Moreover, this method is a new philosophy and manifesto in the education world that can be implemented either in primary or secondary level (Hmelo-Silver, 2004). This method is also a form of a learning approach, which can create active pupils during the learning process. This is because pupils are capable to acquire knowledge and exchange ideas with other friends. This is exceptionally different from conventional and traditional methods where the acquisition of knowledge is only one-way between teachers and pupils. In addition, this method is also seen as a form of learning that cultivates inquiry method by giving emphasis to the problem, the problem solving and the collaboration with other pupils in solving the problem (Savery \& Duffy, 2001). The method is not one that uses a direct modus to resolve the problem but rather involves a process of preparation (Graaff \& Kolmos, 2003), which refers to the development of planning and delivering content-oriented problems and real life problems as a stimulation to increase pupils interest to solve it. There are three key features within the method namely real life problems, group-based process and pupils control. It is also construed as a system of teaching and learning built simultaneously between problem-solving strategies and knowledge based (Barrows, Tamblyn, \& Barrows, 1980). Kilroy (2004) on the other hand stated that this method focuses on the issues or problems that became the starting point of the learning process. Thus, this method has helped to increase students' ability in terms of self-directed learning, critical thinking (Osman, 2013), team working skill, leadership qualities and collaborative learning (Ansari, Rahman, Badgujar, Sami, \& Abdullah, 2015). The method has spread out and has evolved to be used at various educational institutions around the world, not just in health science, but also in other fields such as pedagogy, engineering, nursing, physical therapy, advertising and furthermore architecture. Since the introduction of PBL, there have been a number of systematic reviews published regarding educational potentials, purposes, uses, limitations, effectiveness, and advantages surrounding the application of the method within various domains. Besides, there are many studies comparing this technique with traditional passive approaches in medical education. However, a few limited studies have been done focusing on the disciplines involving problem-based learning and its effect within education. Thus, the purpose of this review is to 
explore the findings of previous studies related to the disciplines involving Problem-Based Learning and its effect within education. For such purposes, the researchers define Problem-Based Learning as a curriculum of carefully selected activities that test the learners' critical knowledge acquisition, self-directed learning, problem solving and also team participation capacities. Within this context, the research questions addressed by this study are: 1) What are the disciplines involving Problem-Based Learning usage in education?; and 2) What are the effects of Problem-Based Learning in education?

\section{Problem Based Learning}

Problem-based learning (PBL) is a learning method that was introduced in McMaster University, Canada in 1969. Following up, this method has been widely used in varieties of disciplines such as management, engineering, agriculture and law. Howard Barrows was one of the academics who pioneered this method at an early stage. Barrows et al. (1980) stated that this method focuses on learning activities that are useful in solving problems of the daily life. It focuses on real issues and challenging it in helping pupils to understand real life situation (Allen et al., 2011). This method also functions as a student-centered model lesson. The concept of PBL method is the result of other learning theories such as Kolb's Theory which emphasizes on experience-based learning, Piaget's Theory, Vgotsky, Lave and Wenger, which focuses on constructivism and social learning and also Schon Theory which concentrates on the reflection process (Sadlo, 2007). The combination of these three theories forms a Problem-Based Learning Model. This method is also known as a form of learning that provides opportunities to the pupils to think and perform self-directed learning. Kitsantas (2013) stated that this method is expected to help pupils to resolve the issues or problems that are provided by using a variety of learning resources. In the context of education, teachers play a role as a facilitator by providing guidance and relevant problems for the pupils to solve it. This means, pupils need to explore actively and contemplate other alternative solutions that are relevant in resolving the issues given by the teacher (Hmelo-Silver, Duncan, \& Chinn, 2007). Teachers are also required to plan lessons properly and determine clear learning objectives. This is to ensure that the issues or problems can be resolved by pupils. Grant (2011) has stated that this method is also able to increase the commitment of pupils in learning. This is because, the approach focuses on teamwork activities, good communication between group members, researching problems and searching information to solve the issues or problems. Besides that, pupils are responsible for their own learning and they will have to share the responsibility between group members to ensure that the given problem is solved. At the same time, PBL also helps pupils to manage their learning time wisely because they need to complete the given task based on a specified time as suggested by Grant (2011). Thus, Piaget (1983) has proposed some of the key elements during the implementation of this method in the classroom which are: 
1) Pupils will be given responsibility in planning their own learning.

2) Problem is the main key in this method.

3) Teachers act as facilitators.

4) Pupils must do reflections.

5) Pupils must learn something in the process of resolving the problem.

In Addition, Graff and Kolmos (2003) have listed nine major principles in this method:

1) Problem is the main element.

2) Student-centred learning.

3) Teachers play roles to create problems that are linked to the pupils' real life.

4) Problem must be related with daily life situations (macam sama ngan (c)).

5) Pupils show interest during the process to resolve the problem.

6) The foundation of this method is learning activities.

7) Pupils have a higher percentage of understanding the topic.

8) Collaboration between group members.

9) A form of active and reflective learning.

In conclusion, the concept of problem-based learning is a form of teaching that focuses on student-centred learning and is based on real life issues or problems. The given problems or issues must be authentic, challenging, complex and unexpected. The implementation of activities and approaches in this method should be broad but the evaluation must be based on specific criteria, which assesses the level of pupils' ability in applying knowledge within the higher level (Hmelo-Silver et al., 2007). On another take, the implementation of this method can change the traditional learning paradigm into the $21^{\text {st }}$ century learning. Thus, the quality of the education system will increase conjunctively alongside other developed countries.

\section{Method}

In this study, a systematic review was chosen in selecting previous studies related to field of PBL. The identification of such relevant studies involves systematic searching of related databases; ERIC and Google Scholar. The process of identification was done within 11 month (July 2018 until May 2019). The purpose of the systematic literature analysis was to develop a structured and reproducible review. The guidelines proposed by Khan (2003) were adapted for the purpose of this study. According to Khan, Kunz, Kleijnen, and Antes (2003), this method been of aid to researchers in critically analysing, evaluating, and synthesising complex ideas. Figure 1 shows the phase of Systematic Literature Review:

\subsection{Framing Questions for a Review}

The review questions were formed based on searches for questions and topics raised in previous studies. The researcher has conducted an initial search to identify previous studies on systematic reviews relating to the implementation of 




Figure 1. Phase in Systematic review.

PBL and specifically, the disciplines involving PBL in formal education and its effects. Researcher found that there were no studies related to the matter, thus this study needs to be done to answer the following questions:

1) What are the disciplines involving Problem Based Learning use in education?

2) What are the effects of Problem Based Learning in education?

\subsection{Identifying Relevant Work}

The duo key processes within this phase were collecting relatively appropriate studies during the preliminary search and accounting the suitability of such studies by means of inclusion and exclusion criteria. "Grey literature"; Discertations, conference proceedings and book chapters were not included to warrant inclusivity. Hence, limitations may be present denoted as "publication bias" (Bernard, Borokhovski, \& Tamim, 2014). Besides that, the search within this study was regulated to full-text articles and peer reviews. Researcher has conducted an initial search using ERIC and Google Scholar within two months by using various key terms such as "Problem Based Learning(PBL)", "the implementation of PBL", "the effect of PBL", "PBL in variety of disciplines" and "PBL in education". During the initial search process, there were two main features considered by researchers which were the title or the abstract. The search terms were refined to include "PBL in the classroom" and "the implementation of PBL in educational institution" to conduct follow-up searches by using the same databases which were ERIC and Google Scholar.

\subsection{Assessing the Quality of Studies}

To ensure the quality of this review, the study selection method was used to select relevance studies to be included in this review. Inclusion and exclusion criteria were used to identify potential primary studies. Such criteria were to choose relevant articles to be included or excluded and those abiding by these 
criteria would be preferred as a part of this study. Thus, the selected studies should have abided by the following inclusion criteria:

1) Published and unpublished studies from 2015-2019.

2) Studies that utilized a PBL programme in formal education.

3) Used research methodologies.

4) Studies that evaluated PBL in formal education.

5) PBL as a tool in teaching and learning.

Alongside that, the exclusion criteria were used to identify irrelevant articles that should not be included in this study. Thus, the exclusion criteria were as follow:

1) PBL not implemented in the education.

2) The articles were not published in 2015-2019.

3) The studies did not evaluate the PBL.

4) PBL not as a teaching and learning tool.

5) Other than journal articles.

There were five (5) inclusion and exclusion criteria used in this study based on the review questions. These criteria were important because it would determine the scope and validity of the systematic review results. The selection process should have followed these criteria starting from the initial evaluation until the final stage of classifying the studies".

\subsection{Summarizing the Evidence}

Google Scholar and ERIC were literature database used to identify relevence studies in this review. Researchers used various key terms such as "Problem Based Learning(PBL)", "the implementation of PBL", "the effect of PBL", "PBL in variety of disciplines" and "PBL in education" during the search process. A total of 305 studies (Google Scholar = 185; ERIC = 120) published from 2015 until 2019 were identified via the two databases. The results were filtered into non-English text and non-journal sources (152 results remained), did not provide the full text (104 results remained), did not meet inclusion criteria (71 results remained) and 30 duplicates were removed. Finally, the researchers identified 43 articles, which the full text was retrieved for further evaluation. Figure 2 shows the PRISMA flow chart that represents the summarizing of searching process.

\subsection{Interpreting the Findings}

To analyze the data, content analysis method was used to interpret the findings. Through the usage of content analysid method, the previous studies' trends were revealed by means of categorical data: quantitative, qualitative and mixed method. From a systematic review of educational researches published between 2015 and 2019 on common disciplines involving Problem-Based Learning and the effects of Problem-Based Learning in formal education, only 43 empirical studies were found and these formed the basis for answering the study questions. 


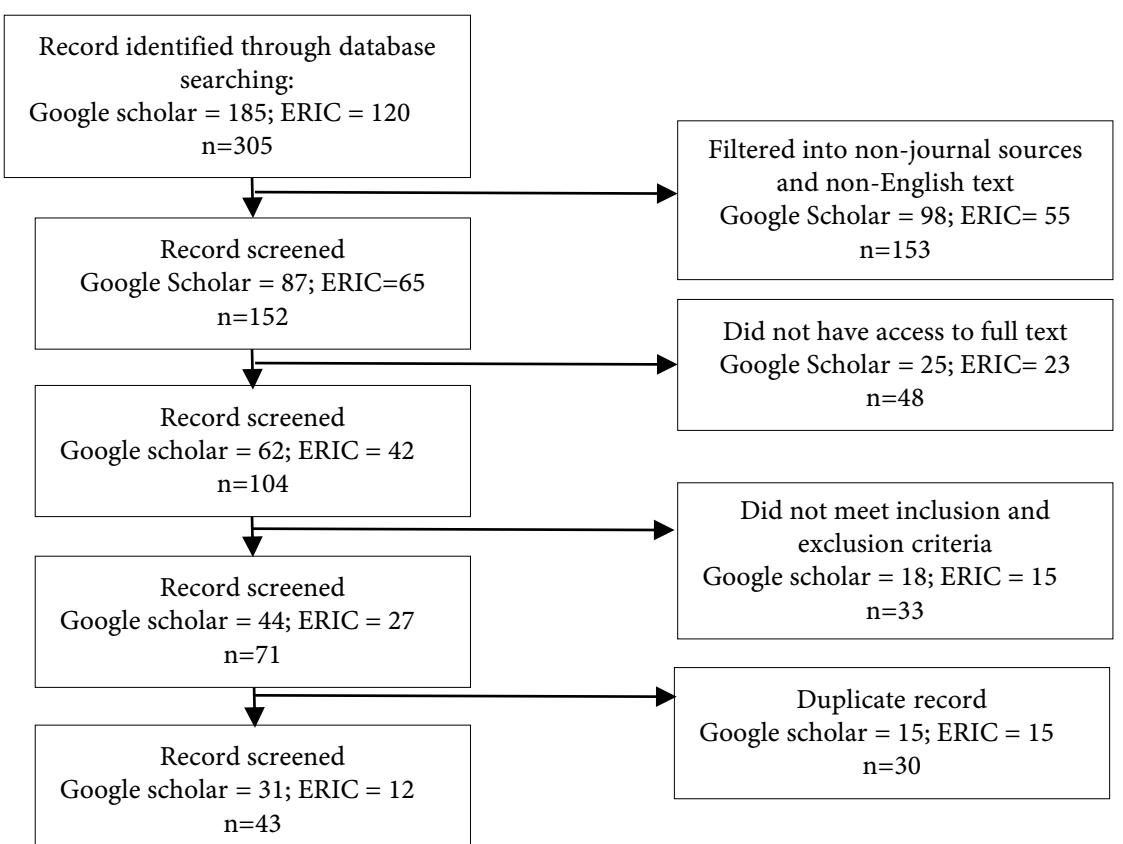

Figure 2. PRISMA flow chart.

The analysis carried out on the methodology used on previous studies from 2015 until 2019 is demonstrated through Table 1. It shows that the quantitative approach was the most practised method used in previous studies compared to others.

\section{Results}

\subsection{Disciplines Involving Problem Based Learning Usage in Education}

Overall, problem-based learning had been used widely in different educational disciplines. The result shows that Mathematics education had a higher number of usage of problem-based learning application followed by Science, Chemistry, Engineering and English. Other disciplines displayed lower value of usage of the problem-based learning in teaching or learning. Table 2 shows the distribution of problem-based learning within educational disciplines:

\subsection{The Effects of Problem Based Learning in Education}

The selected studies show that there are positive impacts in the implementation of problem-based learning in education. Most studies show that problem-based learning promotes collaborative learning and inquiry learning. Table 3 shows the discussion of each study on the effects of problem-based learning application.

\section{Discussion}

From the review, problem-based learning has various impacts in different disciplines of education. This method has been introduced into various teaching 
and learning situations across a number of disciplines within education. The use of PBL in education has been discovered and each study discusses about the relevance of this method in education (Hmelo-Silver, 2004; Pepper, 2014). This method significantly gives impacts towards education (Tarmizi \& Bayat, 2012) and has been developed as an instructional method of hands-on (Ajai \& Imoko, 2014; Dahl, 2018), active learning centred on the investigation (Bilgin, Şenocak, \& Sözbilir, 2009; Mustaffa, Ismail, Tasir, \& Said, 2016; Schettino, 2016; Tarmizi \& Bayat, 2010) and resolution of real world problems. Based on this review, PBL is an established method in Mathematics education that aims to develop reasoning skills (Kazemi \& Ghoraishi, 2012; Lou, Shih, Diez, \& Tseng, 2011; Tarmizi \& Bayat, 2012). More recently, the use of this method aims to improve meaningful learning and is being used as a major educational method in mathematics

Table 1. Numbers of study based on methods.

\begin{tabular}{ccc}
\hline Methods & Google Scholar & ERIC \\
\hline Quantitative & 20 & 9 \\
Qualitative & 11 & 6 \\
Mixed method & 0 & 2 \\
\hline
\end{tabular}

Table 2. Distribution of problem-based learning application.

\begin{tabular}{|c|c|}
\hline Disciplines & Research number \\
\hline STEM & 2 \\
\hline Science & 6 \\
\hline Social Studies & 1 \\
\hline Social Science & 1 \\
\hline Mathematics & 9 \\
\hline Geometry & 1 \\
\hline Chemistry & 5 \\
\hline Psychology & 2 \\
\hline English & 3 \\
\hline Environmental & 1 \\
\hline Engineering & 4 \\
\hline Accounting & 1 \\
\hline Hospitality management & 1 \\
\hline Geography & 1 \\
\hline Pyhsics & 1 \\
\hline Pharmacy & 1 \\
\hline Moral & 1 \\
\hline Computer science & 1 \\
\hline Language course & 1 \\
\hline
\end{tabular}


Table 3. The effects of PBL in education.

\begin{tabular}{|c|c|}
\hline No & Authors \\
\hline 1 & (Kim, Belland, \& Walker, 2018) \\
\hline 2 & (Balim, Inel-Ekici, \& Ozcan, 2016) \\
\hline 3 & (Baysal, 2017) \\
\hline 4 & $\begin{array}{l}\text { (Permatasari, Gunarhadi, \& Riyadi, } \\
\text { 2019) }\end{array}$ \\
\hline 5 & (Fery, Wahyudin, \& Tatang, 2017) \\
\hline 6 & $\begin{array}{l}\text { (Hendriana, Johanto, \& Sumarmo, } \\
\text { 2018) }\end{array}$ \\
\hline 7 & (Duman \& Özçelik, 2018) \\
\hline 8 & (Üce \& Ateş, 2016) \\
\hline 9 & (Baharun, Siraj, \& Ghani, 2017) \\
\hline
\end{tabular}

10 (Ghufron, 2018)

11 (Adanali \& Alim, 2017)

12 (Abubakar \& Arshad, 2015)

13 (Vega \& Navarrete, 2019)

14 (Hernández, Flórez, Tocora, \& León, 2018)

15 (Duda, Susilo, \& Newcombe, 2019)

\section{Effect on implementing PBL in education}

Scaffolding significantly impacted cognitive outcome in PBL.

Student's inquiry-learning skill increased through active learning approaches and self-directed learning in $\mathrm{PBL}$

PBL have positive impacts towards pre-service elementary school teacher on learning, democracy education and skill acquisition.

PBL contributed significantly by impacting in learning interest of elementary school students.

In improving students' mathematical literacy, PBL model was more efficient

Students acquired better grades and relayed positive opinion after getting treatment in PBL.

Self-efficacy abilities can be improved during PBL process.

PBL increased students' achievement in mixed topics.

During PBL process, teachers need to develop tutor skills, facilitator skills and metacognitive skills of students.

PBL have positive impacts in self-directed learning, increase motivation and self-confidence, develop responsibility, create an active learning environment and also increase problem solving skills

PBL lesson able to create an enjoyable lesson, increased students' motivation and also develop cognitive and social skills among students.

Students showed improvement of skills in learning and acquiring information needed to solve problems including life-long learning and information management.

$\mathrm{PBL}$ is a new learning approach alongside gaining practical experience at an industrial scale.

Communication and professional skills of students can be develop through PBL.

Students' science process skill can be influenced with authentic assessment given by teachers.

Its application is suitable to enhance students' higher order mathematical thinking ability as it is capable to condition reflective abstraction concerning mental actions, processes, objects and schemes within students.

17 (Griffith, Butler, Csecs, \& Davis, 2018)

There were positive impacts in leadership skills and team work skills after the implementation of PBL in clinical training.

18 (Li \& Tsai, 2017)

The implementation of PBL helps learners to retain long term knowledge.

$19(\operatorname{Lin}, 2017)$

20 (Gorghiu, Drăghicescu, Cristea, Petrescu, \& Gorghiu, 2015)

(Widyatiningtyas, Kusumah, Sumarmo, \& Sabandar, 2015)

22 (Muñoz Campos, 2017)

23 (Aidoo, Boateng, Kissi, \& Ofori, 2016) Reading comprehension significantly improved alongside strategy used in identification of subject matter within participants.

PBL approach increased students understanding of Science concepts and made students take ownership of their learning.

Significantly impacted their mathematics critical thinking within school level plus prior mathematical abilities by using PBL approach.

PBL assists in building critical thinking skills, self-management skills and knowledge integration.

Problem solving skills and critical thinking can be improved by using PBL method in teaching chemistry.

There were difficulties faced by learners during the process of PBL such as finding the authentic problems and exploring the solutions to the problems.

The integration between PBL and Facebook increased students' achievement in chemistry.

PBL process helps students to built up and enhance their thinking skills, analytical skills, team building skills and also communication skills within a business environment. 


\section{Continued}

27 (Zetriuslita, Wahyudin, \& Jarnawi, 2017)

28 (Serevina \& Sari, 2018)

(Zwaal \& Otting, 2015)

(Sarı, Alıcı, \& Şen, 2017)

31 (Günter \& Alpat, 2017)

32 (Rattanatumma, 2016)

33 (Caesar et al., 2016)

34 (Prayekti, 2016)

(Khumsikiew, Donsamak, \& Saeteaw, 2015)

36 (Nurzaman, 2017)

37 (Beatrice, Amadalo, \& Musasia, 2015) (Brown, Lawless, Rhoads, Newton, \& Lynn, 2016)

39 (Podges \& Kommers, 2017)

$40 \quad$ (Raiyn \& Tilchin, 2015a)

$41 \quad$ (Sedaghat et al., 2017)

42 (Çakiroğlu \& Öztürk, 2017)

(Wardono, Waluya, Mariani, \& Candra, 2016)
Students have problem in developing critical thinking skills during PBL process in Mathematics class.

The implementation of PBL in e-module helps to increase students' science process skill.

The implementation of PBL can be successful if the tutors and students are given a proper training in terms of management.

The uses of PBL in engineering were to develop students' thinking skills and increase their interest in the profesion.

PBL can be used as teaching method to increase students understanding on the given topic.

The groups of students learning via STAD model of cooperative learning displayed higher scores in the post-test measuring mathematics learning achievement and problem solving ability.

Students' engagement can be efficiently enhanced and grasping of geographical content can be improved through PBL activities.

$\mathrm{PBL}$ is one of a method that increase students motivation and form an active learning among students.

Pharmacy students were satisfied and their competencies were enhanced via the PBL course.

Students characters can be improved through PBL process during the process of solving problems.

Encouragement and improvement of linear programming by using this intervention.

Students able to develop their writing skills and actively participate in learning during PBL. This method also create meaningful learning context through the activities.

PBL improves their attitude, motivation and reflection significantly.

PBL changes the relationship between learner and teacher and has an impact at the learner level. In PBL, students can developed various skills and it can effect their best achievement in learning.

Help-seeking skills, task strategies and goal setting and planning were gradually enhanced during this process.

Improvement within mathematics literacy ability was seen as PBL models were used with A PMRI approach assisted by E-Learning platform, Edmodo.

(Mustaffa et al., 2016), that allows students to acquire relevant knowledge and skills in mathematics (Schettino, 2016). Interest on PBL in mathematics has been driven by two factors which are the volume of knowledge and the impact of implementing PBL in the classroom (Tarmizi \& Bayat, 2010). Besides, in the most recent mathematics form, $\mathrm{PBL}$ is thought of as student-centred whereby the pace is set by the students with the teacher as a guide, facilitator and resource (deChambeau \& Ramlo, 2017; Fatade, Mogari, \& Arigbabu, 2013; Sari, Elniati, \& Fauzan, 2014). Besides that, other disciplines also use PBL as a teaching and learning method however the number of researches that touch on those disciplines was strictly limited. For the effects of problem-based learning in education, 95\% of the studies show that PBL has positive impacts towards teaching and learning process. This is due to the reason that PBL is a social constructivism method capable of creating an active learning environment among students (Kirschner Sweller, \& Clark, 2006; Nakada, Okada, Yoshihara, Namiki, \& Hiroi, 2017; Pepper, 2014). This method has a significant relationship with the students' attitude (Lou, Liu, Shih, \& Tseng, 2011; Lou, Shih, et al., 2011; Mataka \& Kowalske, 2015; Tosun \& Senocak, 2013), students achievement (Bilgin, Kara- 
kuyu, \& Ay, 2015; Gallagher \& Gallagher, 2013; Hmelo-Silver, Duncan, \& Chinn, 2007; Ismail et al., 2015; Loyens, Gijbels, Coertjens, \& Côté, 2013; Mokter \& Mahamod, 2016), problem solving (Choi, Lindquist, \& Song, 2014; Jonassen, 2011), students' interest (Jin \& Bridges, 2014; Kim \& Kee, 2013), thinking skills (Basri, Zain, Jaafar, Basri, \& Suja, 2012; Firdaus, Kailani, Bakar, \& Bakry, 2015; Gholami et al., 2016; Raiyn \& Tilchin, 2015b), scientific skills as well as nurturing pedagogical content in technology and also improving positive perceptions in learning (Asyari, Al Muhdhar, Susilo, \& Ibrohim, 2016; Carrió, Larramona, Baños, \& Pérez, 2011).

\section{Conclusion}

Problem-based learning (PBL) is not a new topic in education and has become one of the most powerful learning methods during this educational reform period. As an alternative approach to teaching and learning, PBL has grown to be more known nowadays to the extent of being used in various levels of education and fields. According to these reviews, PBL is widely used in education to help students to learn. PBL is being used as well as adopted onto different disciplines. Those studies modify the PBL for their own purposes in their disciplines. Gradually, various studies were conducted to identify the impact of this method towards different disciplines in education (Chan et al., 2010; Dolmans, Loyens, Marcq, \& Gijbels, 2016; Loyens, Jones, Mikkers, \& van Gog, 2015). The impact of this method towards learners cannot be denied. This method helps to promote students' problem solving skills, communication skills, critical thinking, lifelong learning attitude and also motivate students to learn. PBL holds potential in promoting complex, integrative and highly possible transformative learning, which enables production and creativity within individuals that combine into personal learning. This is due to the reason that learners re-think themselves relatively to the field of problems and context of learning. Overall, PBL should be further developed as an effort to prepare learners with a learning environment identical to the actual clinical environment or practice.

\section{Acknowledgements}

This research was funded by the Dana Pecutan Penerbitan PP-FPEND-2019 by the Faculty of Education, Universiti Kebangsaan Malaysia.

\section{Conflicts of Interest}

The authors declare no conflicts of interest regarding the publication of this paper.

\section{References}

Abubakar, A. B., \& Arshad, M. Y. (2015). Collaborative Learning and Skills of Problem-Based Learning: A Case of Nigerian Secondary Schools Chemistry Students. Asian Social Science, 11, 53. https://doi.org/10.5539/ass.v11n27p53

Adanali, R., \& Alim, M. (2017). The Views of Preservice Teachers for Problem Based 
Learning Model Supported by Geocaching in Environmental Education. Review of International Geographical Education Online, 7, 264-292.

Aidoo, B., Boateng, S. K., Kissi, P. S., \& Ofori, I. (2016). Effect of Problem-Based Learning on Students' Achievement in Chemistry. Journal of Education and Practice, 7, 103-108.

Ajai, J. T., \& Imoko, B. I. (2014). Gender Differences in Mathematics Achievement and Retention Scores: A Case of Problem-Based Learning Method. International Journal of Research in Education and Science, 1, 45-50. https://doi.org/10.21890/ijres.76785

Allen, D. E., Donham, R. S., \& Bernhardt, S. A. (2011). Problem-Based Learning. New Directions for Teaching and Learning, 2011, 21-29. https://doi.org/10.1002/t1.465

Ansari, M. T., Rahman, S. A., Badgujar, V. B., Sami, F., \& Abdullah, M. S. (2015). Problem Based Learning (PBL): A Novel and Effective Tool of Teaching and Learning. Indian Journal of Pharmaceutical Education and Research, 49, 258-265. https://doi.org/10.5530/ijper.49.4.3

Asyari, M., Al Muhdhar, M. H. I., Susilo, H., \& Ibrohim, I. (2016). Improving Critical Thinking Skills through the Integration of Problem Based Learning and Group Investigation. International Journal for Lesson and Learning Studies, 5, 36-44.

https://doi.org/10.1108/IJLLS-10-2014-0042

Baharun, K. A., Siraj, S. A., \& Ghani, M. F. (2017). Penerimaan M-Pembelajaran Dalam Kalangan Pensyarah Institut Pendidikan Guru Malaysia Melalui the Unified Theory of Acceptance and Use of Technology (Utaut): Satu Kajian Awal. Jurnal Kepimpinan Pendidikan, 2, 56-73.

Balim, A. G., Inel-Ekici, D., \& Ozcan, E. (2016). Concept Cartoons Supported Problem Based Learning Method in Middle School Science Classrooms. Journal of Education and Learning, 5, 272-284. https://doi.org/10.5539/jel.v5n2p272

Barrows, H. S., Tamblyn, R. M., \& Barrows (1980). Problem-Based Learning: An Approach to Medical Education. New York: Springer Publishing Company. https://doi.org/10.1080/00365540410018148

Basri, N. E. A., Zain, S. M., Jaafar, O., Basri, H., \& Suja, F. (2012). Introduction to Environmental Engineering: A Problem-Based Learning Approach to Enhance Environmental Awareness among Civil Engineering Students. Procedia-Social and Behavioral Sciences, 60, 36-41. https://doi.org/10.1016/j.sbspro.2012.09.343

Baysal, Z. N. (2017). Pre-Service Elementary School Teachers' Learning Styles and Attitudes towards Mathematics. Educational Research and Reviews, 4, 21-26.

Beatrice, S., Amadalo, N., \& Musasia, M. (2015). Problem Based Learning Technique and Its Effect on Acquisition of Linear Programming Skills by Secondary School Students in Kenya. Journal of Education and Practice, 6, 68-75.

Bernard, R. M., Borokhovski, E., \& Tamim, R. M. (2014). Detecting Bias in Meta-Analyses of Distance Education Research: Big Pictures We Can Rely on. Distance Education, 35, 271-293. https://doi.org/10.1080/01587919.2015.957433

Bilgin, I., Karakuyu, Y., \& Ay, Y. (2015). The Effects of Project Based Learning on Undergraduate Students' Achievement and Self-Efficacy Beliefs towards Science Teaching. Eurasia Journal of Mathematics, Science and Technology Education, 11, 469-477. https://doi.org/10.12973/eurasia.2014.1015a

Bilgin, I., Şenocak, E., \& Sözbilir, M. (2009). The Effects of Problem-Based Learning Instruction on University Students' Performance of Conceptual and Quantitative Problems in Gas Concepts. Eurasia Journal of Mathematics, Science and Technology Education, 5, 153-164. https://doi.org/10.12973/ejmste/75267

Brown, S. W., Lawless, K. A., Rhoads, C., Newton, S. D., \& Lynn, L. (2016). Increasing 
Students' Science Writing Skills through a PBL Simulation. In Proceedings of the 13th International Conference on Cognition and Exploratory Learning in the Digital Age (pp. 86-94). Mannheim: International Association for Development of the Information Society.

Caesar, M. I. M., Jawawi, R., Matzin, R., Shahrill, M., Jaidin, J. H., \& Mundia, L. (2016). The Benefits of Adopting a Problem-Based Learning Approach on Students' Learning Developments in Secondary Geography Lessons. International Education Studies, 9, 51-65. https://doi.org/10.5539/ies.v9n2p51

Çakiroğlu, Ü., \& Öztürk, M. (2017). Flipped Classroom with Problem Based Activities: Exploring Self-Regulated Learning in a Programming Language Course. Educational Technology and Society, 20, 337-349.

Carrió, M., Larramona, P., Baños, J. E., \& Pérez, J. (2011). The Effectiveness of the Hybrid Problem-Based Learning Approach in the Teaching of Biology: A Comparison with Lecture-Based Learning. Journal of Biological Education, 45, 229-235. https://doi.org/10.1080/00219266.2010.546011

Chan, L. K., Patil, N. G., Chen, J. Y., Lam, J. C. M., Lau, C. S., \& Ip, M. S. M. (2010). Advantages of Video Trigger in Problem-Based Learning. Medical Teacher, 32, 760-765. https://doi.org/10.3109/01421591003686260

Choi, E., Lindquist, R., \& Song, Y. (2014). Effects of Problem-Based Learning vs. Traditional Lecture on Korean Nursing Students' Critical Thinking, Problem-Solving, and Self-Directed Learning. Nurse Education Today, 34, 52-56. https://doi.org/10.1016/j.nedt.2013.02.012

Chuan, T. Y., Rosly, N. B., Bin Zolkipli, M. Z., Wei, N. W., Basheer Ahamed, M. A., Binti Mustapha, N. A., Zakaria, Z. et al. (2011). Problem-Based Learning: With or without Facilitator? Procedia-Social and Behavioral Sciences, 18, 394-399. https://doi.org/10.1016/j.sbspro.2011.05.057

Dahl, B. (2018). What Is the Problem in Problem-Based Learning in Higher Education Mathematics. European Journal of Engineering Education, 43, 112-125. https://doi.org/10.1080/03043797.2017.1320354

deChambeau, A. L., \& Ramlo, S. E. (2017). Stem High School Teachers' Views of Implementing PBL: An Investigation Using Anecdote Circles. Interdisciplinary Journal of Problem-Based Learning, 11, Article 7. https://doi.org/10.7771/1541-5015.1566

Didem, İ. E. (2016). Examination of Pre-Service Science Teachers Activities Using Problem Based Learning Method. Educational Research and Reviews, 11, 37-47. https://doi.org/10.5897/ERR2015.2424

Dolmans, D. H. J. M., Loyens, S. M. M., Marcq, H., \& Gijbels, D. (2016). Deep and Surface Learning in Problem-Based Learning: A Review of the Literature. Health Science Education Theory and Practice, 21, 1087-1112. https://doi.org/10.1007/s10459-015-9645-6

Duda, H. J., Susilo, H., \& Newcombe, P. (2019). Enhancing Different Ethnicity Science Process Skills: Problem-Based Learning through Practicum and Authentic Assessment. International Journal of Instruction, 12, 1207-1222.

https://doi.org/10.29333/iji.2019.12177a

Duman, B., \& Özçelik, C. (2018). The Effect of the Creative Drama-Supported Problem-Based Learning Approach on the Self-Efficacy Ability in Geometry. Universal Journal of Educational Research, 6, 2918-2924. https://doi.org/10.13189/ujer.2018.061227

Fatade, A. O., Mogari, D., \& Arigbabu, A. A. (2013). Effect of Problem-Based Learning on Senior Secondary School Students' Achievements in Further Mathematics. Acta Didac- 
tica Napocensia, 6, 27-43.

Fery, M. F., Wahyudin, \& Tatang, H. (2017). Improving Primary Students Mathematical Literacy through Problem Based Learning and Direct Instruction. Educational Research and Reviews, 12, 212-219. https://doi.org/10.5897/ERR2016.3072

Firdaus, F., Kailani, I., Bakar, M. N., Bin, \& Bakry, B. (2015). Developing Critical Thinking Skills of Students in Mathematics Learning. Journal of Education and Learning, 9, 226-236. https://doi.org/10.11591/edulearn.v9i3.1830

Gallagher, S. A., \& Gallagher, J. J. (2013). Using Problem-Based Learning to Explore Unseen Academic Potential. Interdisciplinary Journal of Problem-Based Learning, 7, 111-131. https://doi.org/10.7771/1541-5015.1322

Gholami, M., Moghadam, P. K., Mohammadipoor, F., Tarahi, M. J., Sak, M., Toulabi, T., \& Pour, A. H. H. (2016). Comparing the Effects of Problem-Based Learning and the Traditional Lecture Method on Critical Thinking Skills and Metacognitive Awareness in Nursing Students in a Critical Care Nursing Course. Nurse Education Today, 45, 16-21. https://doi.org/10.1016/j.nedt.2016.06.007

Ghufron, M. A. (2018). The Strengths and Weaknesses of Cooperative Learning and Problem-Based Learning in EFL Writing Class: Teachers and Students' Perspectives. International Journal of Instruction, 11, 657-672.

https://doi.org/10.12973/iji.2018.11441a

Gorghiu, G., Drăghicescu, L. M., Cristea, S., Petrescu, A.-M., \& Gorghiu, L. M. (2015). Problem-Based Learning-An Efficient Learning Strategy in the Science Lessons Context. Procedia-Social and Behavioral Sciences, 191, 1865-1870. https://doi.org/10.1016/j.sbspro.2015.04.570

Graaff, E. D. E., \& Kolmos, A. (2003). Characteristics of Problem-Based Learning. International Journal of Engineering Education, 19, 657-662.

Grant, M. M. (2011). Learning, Beliefs, and Products: Students' Perspectives with Project-Based Learning. Interdisciplinary Journal of Problem-Based Learning, 5, 37-69. https://doi.org/10.7771/1541-5015.1254

Griffith, E., Butler, C., Csecs, J., \& Davis, C. (2018). An Evaluation of a Programme of Problem-Based Learning within a Clinical Psychology Doctorate. Psycology Teaching Review, 24, 38-54.

Günter, T., \& Alpat, S. K. (2017). The Effects of Problem-Based Learning (PBL) on the Academic Achievement of Students Studying "Electrochemistry". Chemistry Education Research and Practice, 18, 78-98. https://doi.org/10.1039/C6RP00176A

Hendriana, H., Johanto, T., \& Sumarmo, U. (2018). The Role of Problem-Based Learning to Improve Students' Mathematical Problem-Solving Ability and Self Confidence. Journal on Mathematics Education, 9, 291-300.

https://doi.org/10.22342/jme.9.2.5394.291-300

Hernández, C. H., Flórez, F. B., Tocora, M. A., \& León, D. G. (2018). Problem Based Learning and the Development of Professional Competences: An Experience in the Field of Biomedical Engineering. Turkish Online Journal of Educational Technology, 17, 104-112.

Hmelo-Silver, C. E. (2004). Problem-Based Learning: What and How Do Students Learn? Educational Psychology Review, 16, 235-266. https://doi.org/10.1023/B:EDPR.0000034022.16470.f3

Hmelo-Silver, C. E., Duncan, R. G., \& Chinn, C. A. (2007). Scaffolding and Achievement in Problem-Based and Inquiry Learning: A Response to Kirschner, Sweller, and Clark (2006). Educational Psychologist, 42, 99-107. 
https://doi.org/10.1080/00461520701263368

Ismail, N. A. S., Alias, E., Arifin, K. T., Damanhuri, M. H. A., Abd Karim, N., \& Aan, G. J. (2015). Perception of Content and Non-Content Expert Facilitators of PBL According to Students' Performance Levels. Pakistan Journal of Medical Sciences, 31, 1537-1541. https://doi.org/10.12669/pjms.316.8691

Jin, J., \& Bridges, S. M. (2014). Educational Technologies in Problem-Based Learning in Health Sciences Education: A Systematic Review. Journal of Medical Internet Research, 16, e251. https://doi.org/10.2196/jmir.3240

Jonassen, D. (2011). Supporting Problem Solving in PBL. Interdisciplinary Journal of Problem-Based Learning, 5, 95-119. https://doi.org/10.7771/1541-5015.1256

Kazemi, F., \& Ghoraishi, M. (2012). Comparison of Problem-Based Learning Approach and Traditional Teaching on Attitude, Misconceptions and Mathematics Performance of University Students. Procedia-Social and Behavioral Sciences, 46, 3852-3856. https://doi.org/10.1016/j.sbspro.2012.06.159

Khan, K. S., Kunz, R., Kleijnen, J., \& Antes, G. (2003). Five Steps to Conducting a Systematic Review. Journal of the Royal Society of Medicine, 96, 118-121.

https://doi.org/10.1258/jrsm.96.3.118

Khumsikiew, J., Donsamak, S., \& Saeteaw, M. (2015). A Model of Small-Group Problem-Based Learning In Pharmacy Education: Teaching in the Clinical Environment. IAFOR Journal of Education, 3, 95-108. https://doi.org/10.22492/ije.3.2.06

Kilroy, D. A. (2004). Problem Based Learning. Emergency Medicine Journal, 4, 411-413. https://doi.org/10.1136/emj.2003.012435

Kim, K. J., \& Kee, C. (2013). Evaluation of an e-PBL Model to Promote Individual Reasoning. Medical Teacher, 35, e978-e983. https://doi.org/10.3109/0142159X.2012.717185

Kim, N. J., Belland, B. R., \& Walker, A. E. (2018). Effectiveness of Computer-Based Scaffolding in the Context of Problem-Based Learning for Stem Education: Bayesian Meta-Analysis. Educational Psychology Review, 30, 397-429.

https://doi.org/10.1007/s10648-017-9419-1

Kirschner, P. A., Sweller, J., \& Clark, R. E. (2006). Why Minimal Guidance During Instruction Does Not Work: An Analysis of the Failure of Constructivist, Discovery, Problem-Based, Experiential, and Inquiry-Based Teaching. Educational Psychologist, 41, 75-86. https://doi.org/10.1207/s15326985ep4102 1

Li, H. C., \& Tsai, T. L. (2017). The Implementation of Problem-Based Learning in a Taiwanese Primary Mathematics Classroom: Lessons Learned from the Students' Side of the Story. Educational Studies, 43, 354-369.

https://doi.org/10.1080/03055698.2016.1277138

Lin, L.-F. (2017). Impacts of the Problem-Based Learning Pedagogy on English Learners' Reading Comprehension, Strategy Use, and Active Learning Attitudes. Journal of Education and Training Studies, 5, 19-125. https://doi.org/10.11114/jets.v5i6.2320

Lou, S. J., Liu, Y. H., Shih, R. C., \& Tseng, K. H. (2011). The Senior High School Students' Learning Behavioral Model of STEM in PBL. International Journal of Technology and Design Education, 21, 161-183. https://doi.org/10.1007/s10798-010-9112-x

Lou, S. J., Shih, R. C., Diez, C. R., \& Tseng, K. H. (2011). The Impact of Problem-Based Learning Strategies on STEM Knowledge Integration and Attitudes: An Exploratory Study among Female Taiwanese Senior High School Students. International Journal of Technology and Design Education, 21, 195-215. https://doi.org/10.1007/s10798-010-9114-8

Loyens, S. M. M., Gijbels, D., Coertjens, L., \& Côté, D. J. (2013). Students’ Approaches to 
Learning in Problem-Based Learning: Taking into Account Professional Behavior in the Tutorial Groups, Self-Study Time, and Different Assessment Aspects. Studies in Educational Evaluation, 39, 23-32. https://doi.org/10.1016/j.stueduc.2012.10.004

Loyens, S. M. M., Jones, S. H., Mikkers, J., \& van Gog, T. (2015). Problem-Based Learning as a Facilitator of Conceptual Change. Learning and Instruction, 38, 34-42. https://doi.org/10.1016/j.learninstruc.2015.03.002

Mataka, L. M., \& Kowalske, M. G. (2015). The Influence of PBL on Students' Self-Efficacy Beliefs in Chemistry. Chemistry Education Research and Practice, 16, 929-938. https://doi.org/10.1039/C5RP00099H

Missildine, K., Fountain, R., Summers, L., \& Gosselin, K. (2013). Flipping the Classroom to Improve Student Performance and Satisfaction. Journal of Nursing Education, 52, 597-599. https://doi.org/10.3928/01484834-20130919-03

Mokter, F. A., \& Mahamod, Z. (2016). Keberkesanan Pembelajaran Berasakan Masalah terhadap Pencapaian dan Kemahiran Berfikir Aras Tinggi Pelajar dalam Karangan Bahasa Melayu. In Seminar Pascasiswazah Pendidikan Bahasa Melayu Dan Kesusasteraan Melayu Kali Kelima (pp. 33-46). Bangi: Faculty of Education, UKM.

Mudrikah, A. (2015). Problem-Based Learning Associated by Action-Process-Object-Schema (APOS) Theory to Enhance Students' High Order Mathematical Thinking Ability. International Journal of Research in Education and Science, 2, 125-135. https://doi.org/10.21890/ijres.88952

Muñoz Campos, D. (2017). Problem-Based Learning: An Experiential Strategy for English Language Teacher Education in Chile. PROFILE Issues in Teachers' Professional Development, 19, 29-40. https://doi.org/10.15446/profile.v19n1.53310

Mustaffa, N., Ismail, Z., Tasir, Z., \& Said, M. N. H. M. (2016). The Impacts of Implementing Problem-Based Learning (PBL) in Mathematics: A Review of Literature. International Journal of Academic Research in Business and Social Sciences, 6, 490-503. https://doi.org/10.6007/IJARBSS/v6-i12/2513

Nakada, A., Okada, Y., Yoshihara, A., Namiki, A., \& Hiroi, N. (2017). Problem-Based Learning. Journal of the Medical Society of Toho University, 65, 1657-1631.

Nurzaman (2017). The Use of Problem-Based Learning Model to Improve Quality Learning Students Morals. Journal of Education and Practice, 8, 234-248.

Osman, M. H. (2013). Ready or Not: Students with Self-Directed Learning? Journal of Engineering Science and Technology, 10, 84-90.

Pepper, C. (2014). Problem-Based Learning (PBL). In R. Gunstone (Ed.), Encyclopedia of Science Education (pp. 1-3). Dordrecht: Springer. https://doi.org/10.1007/978-94-007-6165-0 128-2

Permatasari, B. D., Gunarhadi, G., \& Riyadi, R. (2019). The Influence of Problem Based Learning towards Social Science Learning Outcomes Viewed from Learning Interest. International Journal of Evaluation and Research in Education, 8, 39-46. https://doi.org/10.11591/ijere.v8i1.15594

Piaget, J. (1983). Piaget's Theory. In P. H. Mussen, \& W. Kessen (Eds.), Handbook of Child Psychology: Vol. I History, Theory, and Methods (pp. 41-102). New York: John Wiley.

Podges, M., \& Kommers, P. (2017). Vicarious Learning in PBL Variants for Learning Electronics. Journal of Education and Practice, 8, 5-17.

Prayekti (2016). Effects of Problem-Based Learning Model versus Expository Model and Motivation to Achieve for Student's Physic Learning Result of Senior High School at Class XI. Journal of Education and Practice, 7, 30-37. 
Raiyn, J., \& Tilchin, O. (2015a). Assessment of Adaptive PBL's Impact on HOT Development of Computer Science Students. Journal of Education and Practice, 6, 51-58.

Raiyn, J., \& Tilchin, O. (2015b). Higher-Order Thinking Development through Adaptive Problem-Based Learning. Journal of Education and Training Studies, 3, 93-100. https://doi.org/10.11114/jets.v3i4.769

Rattanatumma, T. (2016). Assessing the Effectiveness of STAD Model and Problem Based Learning in Mathematics Learning Achievement and Problem Solving Ability. Journal of Education and Practice, 7, 194-199.

Sadlo, G. (2007). Problem-Based Learning. British Journal of Occupational Therapy, 60, 447-450. https://doi.org/10.1111/j.1365-2929.2006.02497.x

Sari, S., Elniati, S., \& Fauzan, A. (2014). Pengaruh Pendekatan Pembelajaran Berbasis Masalah Terhadap Kemampuan Pemecahan Masalah Matematika Siswa Kelas Viii Smp Negeri 1 Padang Tahun Pelajaran 2013/2014. Jurnal Pendidikan Matematika, Part, 18, 65-71.

Sarı, U., Alıcı, M., \& Şen, Ö. F. (2017). The Effect of STEM Instruction on Attitude, Career Perception and Career Interest in a Problem-Based Learning Environment and Student Opinions. Electronic Journal of Science Education, 22, 1-20.

Savery, J. R., \& Duffy, T. M. (2001). Problem Based Learning: An Instructional Model and Its Constructivist Framework. Bloomington: The Center for Research on Learning and Technology.

Schettino, C. (2016). Framework for Problem-Based Learning: Teaching Mathematics with a Relational Problem-Based Pedagogy. Interdisciplinary Journal of Problem-Based Learning, 10, Article 12. https://doi.org/10.7771/1541-5015.1602

Schultz, D., Duffield, S., Rasmussen, S. C., \& Wageman, J. (2014). Effects of the Flipped Classroom Model on Student Performance for Advanced Placement High School Chemistry Students. Journal of Chemical Education, 91, 1334-1339. https://doi.org/10.1021/ed400868x

Sedaghat, A., AlJundub, M., Eilaghi, A., Bani-Hani, E., Sabri, F., \& Mbarki, R. (2017). Application of PBL in the Course Fluid and Electrical Drive Systems, Case Study: Manufacturing an Automated Punch Machine. Journal of Problem Based Learning in Higher Education, 5, 48-58.

Serevina, V., \& Sari, I. J. (2018). Development of E-Module Based on Problem Based Learning (PBL) on Heat and Temperature to Improve Student's Science Process Skill. Turkish Online Journal of Educational Technology, 17, 26-36.

Shawver, T. (2015). Building Student Success Using Problem-Based Learning Approach in the Accounting Classroom. Journal of Instructional Pedagogies, 17, 23-38.

Sunar, M. S. M., \& Shaari, A. J. (2017). The Effectiveness of the Chemistry Problem Based Learning (PBL) via FB among Pre-University Students. Journal of Education and E-Learning Research, 4, 129-138. https://doi.org/10.20448/journal.509.2017.44.129.138

Tarmizi, R. A., \& Bayat, S. (2010). Effects of Problem-Based Learning Approach in Learning of Statistics among University Students. Procedia-Social and Behavioral Sciences, 8, 384-392. https://doi.org/10.1016/j.sbspro.2010.12.054

Tarmizi, R. A., \& Bayat, S. (2012). Collaborative Problem-Based Learning in Mathematics: A Cognitive Load Perspective. Procedia-Social and Behavioral Sciences, 32, 344-350. https://doi.org/10.1016/j.sbspro.2012.01.051

Tosun, C., \& Senocak, E. (2013). The Effects of Problem-Based Learning on Metacognitive Awareness and Attitudes toward Chemistry of Prospective Teachers with Different Academic Backgrounds. Australian Journal of Teacher Education, 38, 61-73. 
https://doi.org/10.14221/ajte.2013v38n3.2

Üce, M., \& Ateş, İ. (2016). Problem-Based Learning Method: Secondary Education 10th Grade Chemistry Course Mixtures Topic. Journal of Education and Training Studies, 4, 30-35. https://doi.org/10.11114/jets.v4i12.1939

Vega, F., \& Navarrete, B. (2019). Professional Design of Chemical Plants Based on Problem-Based Learning on a Pilot Plant. Education for Chemical Engineers, 26, 30-34. https://doi.org/10.1016/j.ece.2018.08.001

Wardono, Waluya, S. B., Mariani, S., \& Candra, S. D. (2016). Mathematics Literacy on Problem Based Learning with Indonesian Realistic Mathematics Education Approach Assisted E-Learning Edmodo. Journal of Physics: Conference Series, 693, Article ID: 012014. https://doi.org/10.1088/1742-6596/693/1/012014

Widyatiningtyas, R., Kusumah, Y. S., Sumarmo, U., \& Sabandar, J. (2015). The Impact of Problem-Based Learning Approach to Senior High School Students' Mathematics Critical Thinking Ability. Journal on Mathematics Education, 6, 30-38. https://doi.org/10.22342/jme.6.2.2165.107-116

Zetriuslita, Z., Wahyudin, W., \& Jarnawi, J. (2017). Mathematical Critical Thinking and Curiosity Attitude in Problem Based Learning and Cognitive Conflict Strategy: A Study in Number Theory Course. International Education Studies, 10, 65-78. https://doi.org/10.5539/ies.v10n7p65

Zwaal, W., \& Otting, H. (2015). Aligning Principles and Practice in Problem-Based Hospitality Management Education. Journal of Hospitality, Leisure, Sport and Tourism Education, 16, 22-29. https://doi.org/10.1016/j.jhlste.2015.01.001 